\title{
O regime de autoria e os lugares pa- ratópicos encontrados nas corres- pondências erótico-poéticas entre Gregório de Matos e Guerra e Soror Violante do Céu
}

André da Costa LOPES

Ricardo CELESTINO

\section{Considerações iniciais}

Neste capítulo, temos como tema de pesquisa o estudo do regime de autoria e dos lugares paratópicos encontrados na troca de correspondências poéticas entre os poetas Gregório de Matos e Guerra e Soror Violante do Céu. Gregório de Matos é conhecido por discursos literários que satirizam o cotidiano secular e sacro do século XVII, de forma a trafegar entre as antíteses da beleza 
de uma sexualidade sagrada e da imoralidade de uma sexualidade mundana. Violante do Céu, por sua vez, ficou conhecida em sua época por seus trabalhos missionários e pela composição de Décima Musa e Fénix dos Engenhos Lusitanos, cultivando estratégias de composição enunciativo-discursivas que privilegiam a construção mental de conceitos e a elegância na sutileza.

Compreendemos que o regime de autoria presente nos discursos literários seiscentistas implica a imitação de discursos-modelo e a repetição de tópicas pertencentes ao código de escrita retórico-poético que fundamenta as rotinas enunciativo-discursivas de gêneros de discurso literário. A correspondência burlesca entre um poeta e uma poetiza de renomada vida espiritual e religiosa nos permite questionar de que maneira os discursos literários seiscentistas que abordam o erotismo mundano podem se tornar respeitáveis e engenhosos, dadas às condições sócio-histórico-culturais de produção.

Identificamos ao longo da pesquisa que os discursos literários possibilitam espaço para enunciados eróticos, quando as cenas que emergem na enunciação autorizam novos lugares e novos papeis que transcendam os lugares e os papeis atópicos e legitimados como imorais no século XVII. Nesse caso, o discurso literário permite que certas práticas reprimidas pelo código ético-político seiscentista encontrem um lugar provisório de existência desde que sejam vistos como verossímeis e que possam gerar no leitor um sentimento de deleite e aprendizado. $\mathrm{Na}$ lógica da estética da imitação, determina-se que se imite não o igual, mas o semelhante. Desse modo, somente por intermédio dos jogos engenhosos de linguagem é que pode instaurar novas enunciações e, com isso, novos posicionamentos enunciativos. $\mathrm{O}$ que melhor busca a semelhança entre as coisas é a metáfora que, em sua forma mais perfeita, torna-se agudeza. Encontrar relações improváveis entre os sentidos e 
as coisas é trabalho do engenho do poeta que busca desvendar, tal qual o filósofo, a verdade no mundo das aparências.

Para fundamentar este estudo, selecionamos como aparato teórico-metodológico a Análise do Discurso proposta por Dominique Maingueneau (2008, 2015), especificamente a categoria de paratopia, a qual permite analisarmos como a enunciação literária tem o poder de desestabilizar as representações dos lugares tópicos e instituídos em uma sociedade, inaugurando novas possibilidades de lugares simultaneamente possíveis e impossíveis.

Organizamos nosso capítulo inicialmente apresentando as conjunturas da enunciação literária no século XVII, privilegiando as categorias da imitação, da metáfora e da agudeza. Em seguida, refletimos sobre as múltiplas racionalidades da verdade presentes no imaginário seiscentista, na perspectiva dos estudos filosóficos de Leibniz (1987, 1992) e Gassendi (1964). Adiante, destacamos as contribuições da Análise do Discurso para o estudo de discursos literários. Selecionamos as categorias de discursos constituintes, paratopia e autoria como fundamentação teórica de nossa pesquisa. Por fim, apresentamos os resultados obtidos em nossa análise da décima de Soror Violante do Céu, remetida ao poeta Gregório de Matos.

\section{As conjunturas da enunciação literária no século XVII: imitação, metáfora e agudeza}

No século XVII, as práticas sociodiscursivas eram normatizadas por um código de linguagem retórico-poético constituído, principalmente, por releituras da Arte Retórica e da Arte Poética aristotélica. A forte normatização dos modos de enunciar deu certo tom de literalidade às práticas linguageiras. Nesse sentido, tudo 
que o código de linguagem retórico-poético possibilitava produzir, desde tratados de agricultura a súmulas teológicas, tinha em si uma proximidade com o discurso literário.

Mas o que distingue certas práticas verbais seiscentistas para que se possa considerá-las pertencentes ao discurso literário é, sobretudo, sua condição de produção verbal verossímil pautada na imitação de discursos-modelo ${ }^{32}$. Foi Aristóteles (2007), na Arte Poética, e seus seguidores latinos que definiram os pilares conceituais desse modo peculiar de escrever que necessitou de um discurso apartado da retórica: a Arte Poética.

Segundo o código poético-discursivo que normatiza o discurso literário, o fim ou o meio de toda a escrita literária é a imitação de ações humanas, com intuito de captar não o particular, mas o universal. Em um enunciado poético grave o que importa não é o herói em si, mas suas ações virtuosas. Nesse sentido, as práticas de escrita literária também se diferenciam por sua função social: deleitar e instruir. Esses dois princípios estão presentes em conceitos, como o de katarsis, prodesse aut delectare e no dulte et utile horaciano que têm por finalidade ativar efeitos psicológicos no ouvinte/leitor.

Para Aristóteles (2007) imitar faz parte da natureza humana. É por meio da imitação, inclusive, que se alcança o conhecimento:

A tendência para a imitação é instintiva no homem, desde a infância. Neste ponto distinguem-se os humanos de todos os outros seres vivos: por sua aptidão muito desenvolvida para a imitação. Pela imitação adquirimos nos-

32 A noção de discurso-modelo pode estar associada a um discurso de um auctor pertencente ao arquivum literário barroco ou a um enunciado de autoria dispersa, partilhado coletivamente, o qual tem a função literária de um mote a ser glosado. 
sos primeiros conhecimentos, e nela todos experimentamos prazer (op. cit, p. 244).

$\mathrm{O}$ argumento aristotélico considera o imitar inerente a todo ser humano, especialmente pelo fato de ser uma forma natural de adquirir conhecimento, através do qual se experimenta o prazer. Vale ressaltar que, nessa perspectiva, as produções discursivas literárias não são entendidas como cópias servis, mas como imitações que buscam captar a essência da coisa imitada. Ao se fazer isso, alcança-se o conhecimento e o prazer.

Muhana (1997) considera que, enquanto princípio da ação do poeta, a imitação parte da natureza. Imitar é um procedimento natural e quando o poeta imita, ele imita a natureza. Imita-a, não como ela se apresenta, mas sim de acordo com uma lógica que considera as relações de semelhança. Isso quer dizer que o poeta não copia, mas refaz a natureza por meio de operações racionais que buscam, sobretudo, entender como atua a natureza e os homens. Desse modo, torna-se possível superar a natureza ao passo que a imitação é capaz de depurar suas "imperfeições".

É nesse sentido que no século XVII, a imitação pautou-se exclusivamente em discursos-modelo, principalmente àqueles advindos da antiguidade. Passou-se a ter como parâmetro essencial uma segunda natureza: "a natureza aperfeiçoada pelos poetas antigos - destituída de supérfluo e do defeituoso, conhecedora da arte e de suas razões, dos seus princípios e dos seus fins" (MUHANA, 1997, p. 41).

Ao interessar-se não apenas pelas ações humanas, mas também pelos discursos, o discurso literário aproxima-se do código de linguagem retórico. Isso quer dizer que a produção literária, no século XVII, passará a seguir as normas não só do código de 
linguagem poético, mas também do retórico. Tal união acaba por fundir duas noções centrais: a de verossimilhança poética e a de conveniência retórica. $\mathrm{O}$ verossímil busca captar o universal das coisas, mesmo em coisas particulares, de modo que se possa criar um efeito de aparência de verdade. A conveniência retórica está relacionada ao respeito ao estatuto enunciativo do gênero de discurso, no que diz respeito, principalmente, à linguagem adequada a cada situação de enunciação.

No século XVII, as principais premissas dos conceitos de verossimilhança e de conveniência retórica se fundem à noção de decoro. É por meio desta última noção que as normas de composição de cada gênero de discurso literário são estabelecidas. Os preceptistas encontrarão respaldo para uma normatização do decoro nas considerações sobre o estilo presentes na poética e na retórica aristotélica. Na retórica, há três estilos de dizer: humilde, medíocre e grave; há também três gêneros de discurso retóricos: judiciário, deliberativo e demonstrativo. Na poética, há três espécies imitativas: cômica, trágica e épica. Sendo que cada uma detém seu próprio verossímil.

No caso específico do discurso literário, gêneros de discurso como a tragédia e a épica pertencem aos gêneros graves; já a comédia pertence aos gêneros baixos. De um modo mais geral, é a temática do enunciado literário, séria ou cômica, que define seu pertencimento aos gêneros graves ou aos baixos. No que concerne ao estilo e às estratégias argumentativas, o gênero retórico demonstrativo, pelo qual se normatiza os modos de enunciar louvores e vitupérios; e o estilo mediano e sublime ${ }^{33}$, que tem por finalidade enunciativa deleitar e mover norteiam as normas de composição

33 Conforme Muhana (2002) a divisão dos estilos retóricos identifica nos discursos uma aparência de baixo, medíocre e elevado, relacionados às estratégias de convencimento do enunciador em relação ao co-enunciador: baixo ou simples ao provar; medíocre ou mediano ao deleitar; elevado ou sublime ao mover. 
dos gêneros de discurso literários. A teoria da divisão dos estilos abriu caminho para que o discurso literário ampliasse as possibilidades temáticas e enunciativas. Fato que deu mais liberdade a poetas burlescos e satíricos para lidar com matéria torpe, ou seja, lidar com discursos que ferem o código ético-político partilhado pela sociedade seiscentista em nome da correção dos vícios.

Embora a noção de separação de estilos determine o uso comedido de figuras e certa clareza na linguagem, no século XVII, a ideia de embelezamento e elegância do discurso não está relacionada apenas à escolha refinada de itens lexicais ou à construção de frases e versos bem formados, mas também ao uso de recursos poético-discursivos. Entre tais recursos estão as figuras de linguagem e os silogismos retóricos, responsáveis por acionar os jogos de sentido no enunciado literário.

O recurso poético-discursivo central para o código de linguagem literária seiscentista são as agudezas. No século XVII, agudeza é sinônimo de metáfora ou conceito, principalmente por operar relações entre conceitos distantes, gerando relações de sentido inesperadas. De acordo com Baltazar Gracián (1944), as operações metafóricas são possíveis maneiras de construir agudezas, as quais se fundem em algum "sutilíssimo artifício" capaz de aturdir o entendimento.

Teixeira (2005) descreve a metáfora seiscentista como a mais aguda e engenhosa conquista do entendimento humano, porque, de uma só vez, é capaz de aproximar propriedades distantes e de explicar um conceito por meio de outro muito distinto. Por isso, esta figura, entendida como analogia engenhosa, é muitas vezes tida como sinônimo de agudeza. A noção de agudeza, contudo, é instável podendo ser concebida como imagem resultante da aplicação consciente do engenho, ou seja, materialização poético-discursiva operada pela força criadora do intelecto humano; ou assu- 
mir formas as mais variadas desde a metáfora ao silogismo. Além disso, pode se manifestar em outras linguagens, como na pintura, na escultura e até mesmo nas ações humanas.

Conforme Aristóteles (2007), a arte da imitação consiste em imitar não o igual, mas o semelhante. Nesse sentido, a metáfora é a melhor maneira de fazer isso, pois capta a natureza das coisas exatamente por meio de analogias: analogias entre a imagem do pensamento e as palavras; analogia entre as palavras e as coisas; analogias entre sentidos distantes. No século XVII, a agudeza é essa força metafórica capaz de criar verossímeis poéticos e de desvelar o universal no particular das coisas. Compreendemos que, nos discursos literários seiscentistas, a agudeza funciona como uma estética para o estabelecimento de uma enunciação da Verdade. Dessa maneira, entendemos ser imprescindível refletir sobre a Verdade e suas múltiplas racionalizações no século XVII.

\section{As múltiplas racionalizações da verdade}

O pensamento filosófico do século XVII se constitui, além da lógica cartesiana de Descartes, de correntes que refletem sobre a relativização em torno do racionalismo lógico-cartesiano, dos quais destacam os pensadores Gassendi (1964) e Leibniz (1987; 1992). Com o intuito de priorizar o estudo de um pensamento filosófico que reflita sobre as múltiplas lógicas que condicionam à verdade, compreendemos que os estudos desses filósofos destacados possibilitam uma maior clareza no pensamento lógico do homem barroco.

Gassendi (1964) propõe um estudo filosófico que destaca o atomismo como uma explicação possível sobre a matéria e a organização da natureza. Os atomistas defendem que o mundo pode 
ser reconhecido pelos sentidos e a ciência é válida quando suas inferências são pautadas nos dados das aparências. Parte do pressuposto que o homem sempre terá uma limitação que dificulta sua capacidade em elucidar a verdadeira natureza das coisas. Dessa maneira, só é possível traçar explicações das causas das experiências. O conhecimento, que no racionalismo proposto por Descartes é a plenitude almejada em todo processo científico, na perspectiva atômica é resultado de uma explicação cuidadosa das aparências e uma avaliação dos dados derivados dela. O cientista ou o filósofo investiga e passa a conhecer as condições que fazem a experiência um acontecimento possível e inteligível.

$\mathrm{O}$ atomismo permite explicar qualidades sensíveis da experiência e promover um modelo para dados conhecidos sobre o mundo observado. Sinais indicativos experimentais são observados como qualidades sensoriais encontradas na natureza. Os dados sensórios apresentados pelo mundo são inteligíveis ao homem e Gassendi (1964) busca na filosofia encontrar um conhecimento provável das aparências e traçar um meio termo entre os céticos, observando que nem tudo que colocam como tema de debate é plenamente desconhecido, e os dogmáticos, que não conhecem plenamente tudo que acreditam conhecer. O conhecimento, nesse sentido, é constituído de enunciados prováveis pautados na experiência do fenômeno, valorizando o conteúdo da sensação, distinguindo-a em verdades da existência e verdades de julgamento. A verdade da existência consiste na genuinidade das coisas, contrária ao valor de verdade das proposições. A verdade do julgamento se aplica às proposições sobre os referentes externos das sensações. O erro incide na verdade em julgamento, já que o homem faz julgamentos errôneos sobre os referentes de suas sensações.

Outra contribuição do atomismo para revelar a complexidade do pensamento do homem barroco é a infabilidade dos sentidos 
perante o intelecto. Gassendi (1964) observa que cada ação do intelecto é resultado de uma necessidade de se aproximar o máximo possível da conformidade com a coisa observada. A busca pelo sentido único leva a construção de argumentos com base nas sensações, já que concentram um olhar em uma variedade de experiência individual que gera um conjunto de sentenças pseudoverdadeiras sobre a coisa observada. Dessa maneira, as investigações filosóficas se restringem aos desdobramentos das aparências, já que buscar um conhecimento inato das coisas é impossível. Há, assim, uma negação em torno do ato de penetrar na natureza íntima das coisas e a contemplação de verdades que estão sempre sujeitas a falhas, embora se projetem como infalíveis.

Leibniz $(1987,1992)$ também desenvolve estudos acerca do universo do sentido das coisas, a fim de individualizar a Verdade, a partir de um sistema coeso de reflexões pautado em fontes heterodoxas. $\mathrm{O}$ filósofo busca responder principalmente às perguntas propostas pela filosofia moderna de Descartes, ao mesmo tempo em que incorpora boa parte do legado escolástico da Filosofia Medieval.

O ponto de partida dos estudos de Leibniz $(1987,1992)$ é idealizar uma teoria da expressão que contemple as aporias Deus e religião, assim como indivíduos e moral. Com o intuito de centralizar o uso da lógica para a construção de sentidos, o pensador analisa a correspondência sagrada entre o que dizer da expressão e o que dizer do exprimido, o que lhe permite propor uma filosofia plural, que nos oferta ferramenta para refletir sobre o funcionamento dos discursos religiosos, teológicos, ontológicos e epistemológicos seiscentistas no que diz respeito à busca pela Verdade.

Na Teoria de métodos variáveis, Leibniz $(1987,1992)$ estabelece leis de semelhança entre questões antagônicas, permitindo a construção de analogias equidistantes, que geram um conjunto de 
aporias que o filósofo busca solucionar.

A primeira aporia é o esforço em tornar comensurável o que é incomensurável. Leibniz $(1987,1992)$ propõe para essa questão a lógica infinitesimal que permite chegarmos matematicamente ao valor exato de uma grandeza incomensurável. Cada uma das séries correlacionadas é governada por uma razão própria, com a possibilidade de uma ser tomada pela razão outra, a partir do conhecimento profundo de ambas as particularidades. Em outras palavras, propõe uma relação regrada e recíproca de valores, que possibilita conhecermos, observarmos, pensarmos, lermos e construirmos um pelo outro.

A segunda aporia que Leibniz $(1987,1992)$ se depara é refletir sobre o fato do comensurável só exprimir o incomensurável devido a um gesto do enunciador em aniquilar as diferenças presentes no discurso. A diferença é pensada e se perde na identidade, o que proporciona a complexidade da expressão. Embora o exprimido seja incomensurável, a força que o torna comensurável garante-lhe uma possibilidade de expressão que carrega essência única. Nesse sentido, o tudo em expressão tem relevância temporária no aqui e na parte que o expressa.

Por fim, Leibniz $(1987,1992)$ fundamenta a terceira aporia a partir da relação entre unidade e multiplicidade. A unidade pode ser exprimida por uma série infinita de combinações que levam a ideias divergentes. A conciliação entre a simplicidade divina e a multiplicidade de ideias envolve a criação de substâncias reais que se distinguem entre si. A distinção de formas reais se dá por conta de distinções racionais e discursivas de um e de outro e não pela unidade exprimida. A relação entre divino e variedade de ideias o possibilita refletir sobre a característica universal da unidade exprimida. Os pensamentos simples são considerados elementos da característica e as formas simples, a fonte das coisas. Todas as 
formas simples são compatíveis entre si e expressam pensamentos simples e cotidianos. As ideias convêm com as Ideias de Deus ou do Universal e as exprimem. Há, assim, compatibilidade entre as formas e os fundamentos que caracterizam Deus em sua totalidade e sua característica universal seria a atribuição de todas as ideias em um formato ou ornato próprio. O filósofo, dessa maneira, concebe a Deus um corpo e uma essência com semelhanças mundanas sem subtraí-lo das concepções teocêntricas cristãs.

\section{As contribuições da Análise do Discurso em estu- dos de discursos literários}

Como observamos em nossas considerações iniciais, fundamentamos nossa pesquisa pelos pressupostos teórico-metodológicos da Análise do Discurso desenvolvida por Maingueneau (2008; 2015). Compreendemos que categorias como discurso constituinte, paratopia e autoria contribuem para a análise de discursos literários, tomando como ponto de partida a relação do funcionamento enunciativo-discursivo com as múltiplas práticas sócio-culturais seiscentistas. $\mathrm{O}$ discurso literário seiscentista funciona como um catalisador de complexidades subjetivas que envolvem o cerne das instituições sociais do século XVII e acreditamos que as categorias propostas por Maingueneau (2015) nos auxiliam a enxergar com mais clareza esse mosaico complexo da vida social e cultural da época. Dessa maneira, dividimos a exposição da fundamentação teórica de nossa pesquisa em três partes: o discurso literário como discurso constituinte; a enunciação paratópica; o regime de autoria de um enunciador de um discurso literário. 


\section{O discurso literário como discurso constituinte}

Maingueneau (2008) compreende que há uma tendência, ao longo do tempo, em sobrepor os textos rotineiros, aos textos literários. Discursos que encontramos nas práticas discursivas cotidianas, como a notícia, a carta comercial, o artigo de opinião, possuem determinações distintas daqueles que socialmente são definidos como artísticos, científicos, filosóficos ou teológicos. Estes últimos são considerados historicamente como bem-sucedidos. É caso dos discursos teológicos de São Tomás de Aquino ou da Filosofia proposta por Descartes. O discurso literário também se insere nesse tipo de plano de produção enunciativo-discursiva, que Maingueneau (2015) denomina discursos constituintes.

Maingueneau (2015) observa que como todo discurso constituinte, o literário detém um archeion de uma coletividade ligado a discursos fundadores que pressupõem mandamentos e poder sobre a prática enunciativo-discursiva. Sede de autoridade, o archeion associa-se a determinação de um lugar vinculado com um corpo de locutores consagrados e a uma memória em constante desenvolvimento. Por deter um archeion, tais discursos conferem sentido aos atos da coletividade, assumindo muitas vezes a função de garantes de múltiplos gêneros de discurso. Dotados de um estatuto singular, já que incidem em falas que se pretendem superiores a todas as outras, embora se situem entre elas, os discursos literários autorizam a si mesmos ao mesmo tempo em que se propõem ligados a uma fonte legitimadora, o que os definem como auto e heteroconstituintes.

Observar a constituência literária pressupõe mostrar vínculo entre o intra e o extradiscursivo, bem como a imbricação entre o textual e a atividade enunciativa. A enunciação passa a ser o dispositivo de legitimação de seu próprio espaço, incluindo até mesmo 
o aspecto institucional que autoriza esse lugar discursivamente. Articulam-se, assim, o engendramento do texto e a forma que ele se inscreve no universo social, elementos esses que não são dissociáveis, já que não há dissociação entre as operações enunciativas em que se institui o discurso e o modo de organização institucional que o discurso pressupõe e estrutura.

Maingueneau (2008) observa que cada discurso assume a constituência de uma maneira específica. Embora o discurso literário seja um discurso constituinte, não podemos confundi-lo com um discurso fundador. Há no discurso literário uma instância enunciadora que irá gerenciar o estatuto constituinte do discurso, projetando-se em um limite último, já que participa tanto do mundo humano como de forças transcendentais de campos como a filosofia, a religião, a ciência, dentre outros. A maneira de gerir a constituência no discurso literário é apresentar, então, sua fala na cumplicidade com a voz do Outro.

Maingueneau (2015) reflete sobre a forma do conteúdo como semelhante à forma de expressão no discurso literário. O texto literário é seu modo de dizer, ao contrário da filosofia e outros discursos constituintes que se esforçam na legitimidade de seus conteúdos em fórmulas de dizer prontas. Assim, o determinante para o discurso literário é sua traduzibilidade, pois a forma do conteúdo pela constituição da figuração da forma expressiva se dá sobre o grau de literariedade e de filosoficidade do discurso. A filosofia, de um lado, assume um regime especulativo de constituência, enquanto a literatura explora um universo ficcional das possibilidades. Não há, assim, um discurso puramente literário, mas a constituência se dá na convergência entre combinações dos campos literário e filosófico. A promoção da inter-relação do estético literário e do ético-epistemológico filosófico determina, de um lado pelo literário, efeitos de real e sinestesia estética; de outro, pelo 
filosófico, o fazer da obra como o fazer do mundo e a mobilidade de dimensões estético-pragmáticas.

\section{A enunciação paratópica}

A produção de enunciados reconhecidos como literários demanda uma apresentação do sujeito-enunciador, definida com as representações e os comportamentos associados à condição de ser enunciador de um discurso literário. A produção literária é compreendida como um discurso que não remete primeiramente à sociedade, mas segundo Maingueneau (2015), a um setor limitado dela, de um campo relativamente unificado de regras específicas. A obra literária participa de três planos do espaço literário, sendo eles: a rede de aparelhos, o campo discursivo e o arquivo.

A rede de aparelhos pressupõe o lugar pelo qual os indivíduos se constituem como enunciadores: garantidos e estabilizados pelos contratos genéricos. Sistema que integra instâncias diversas, conjuntos de práticas e discursos possíveis e que viabilizam a existência da enunciação literária.

O campo discursivo constitui lugar de confronto de posicionamentos estéticos que afetam a constituição dos gêneros. Diferentes posicionamentos se encontram em concorrência em sentido amplo e delimitam-se mutuamente, a fim de proporcionar uma autoridade enunciativa. O campo discursivo é uma estrutura instável, onde há posicionamentos dominantes e dominados, centrais e periféricos.

O arquivo refere-se à combinação de intertexto e lendas, já que a atividade criadora está inserida em uma memória, apreendida pelos conflitos do campo discursivo, constantemente retrabalha- 
das. $\mathrm{O}$ arquivo designa a memória interna da literatura.

Em face ao exposto, compreendemos que a enunciação literária desestabiliza representações de lugar. Os meios literários funcionam como fronteiras e a existência social da literatura supõe ao mesmo tempo a impossibilidade de ela se fechar em si e de se confundir com a sociedade comum. A instituição literária se mantém nas fronteiras entre a inscrição tópica e o abandono a forças que excedem a economia humana. Maingueneau (2008) afirma que os processos criadores que instituem o discurso literário se alimentam de lugares, grupos, comportamentos tomados em um pertencimento impossível. A literatura se compara a uma rede de lugares na sociedade, não podendo se encerrar em nenhum território. $\mathrm{O}$ pertencimento ao campo literário não é uma negociação entre o lugar e o não-lugar, parasitário, mas a instituição de uma inclusão social impossível.

A maneira como o discurso literário se insere no espaço social pressupõe um ato de criação autoral das próprias condições de criação. Maingueneau (2015) observa que todo enunciador de um discurso literário gere sua maneira de duplo pertencimento, quer seja da sociedade tópica, quer seja das redes dessa topia. Denomina paratopia, nesse sentido, o ato de explorar as fendas que não cessam em abrir na sociedade, em uma prática enunciativo-discursiva com pretensões de universalidade, mas de emergência local. Desse modo, o discurso paratópico se constitui por meio da absorção das normas e dos realces de força dos lugares tópicos. $\mathrm{O}$ enunciado literário surge das tensões do campo literário com outros campos, a fim de suprir as angústias de dizer sobre o mundo, colocando em jogo na enunciação os problemas de uma impossível inscrição social da própria enunicação.

A enunciação literária se desenvolve em sociedades restritas que gozam de relativa autonomia e o sujeito-enunciador ocupa 
uma posição de instabilidade e faz do lugar de enunciação um local ambivalente. Há, dessa maneira, afinidades que trafegam entre o parasitismo da mundanidade. Como observa Bauman (1999), as instituições sociais se organizam a fim de conservar uma racionalidade de normas, rituais, contratos, em um contexto de indiferença e invisibilidade da complexidade dos sujeitos que as compõem. Funcionando como lupa que desvela as contradições da sociedade, o discurso literário auxilia na visibilidade da moral do Outro, colocando-o em existência e em pertencimento a um mundo de fragmentações. A racionalidade subjaz, nesse sentido, uma construção institucional que traduz o sentido que melhor representa os anseios existenciais do grupo que a origina, buscando priorizar sua sobrevivência e legitimidade. Em contrapartida, o discurso literário se apropria dos ecos deixados pelos discursos tópicos e explora os tons de cinza que envolvem o Outro e sua (in) adequação às normas vigentes.

O sujeito-enunciador está na fronteira móvel entre a sociedade e um espaço paratópico. Essa condição possibilita estruturar o que há de insustentável em sua posição, como uma espécie de zona franca, sem tributações na sociedade, já que esta permite ao enunciador um pertencimento desenraizado. Maingueneau (2015) observa que o enunciador do discurso literário se relaciona, de forma singular, com uma sociedade fortemente tópica e com espaços cuja utopia seja mais líquida e alimente o trabalho criador. O lugar social do qual o enunciador denuncia certas faltas se encontra construído na enunciação. A cena enunciativa mostra um lugar que remete certa ficcionalização às suas condições de possibilidade de existência. Há uma irredutibilidade da vida, consequência do paroxismo do mundo dos fingimentos e máscaras que sustentam o discurso. 


\section{O regime de autoria de um enunciador de um dis- curso literário}

No âmbito da criação, a escrita literária seiscentista, por ter como norte um código de linguagem retórico-poético e por se enquadrar numa poética da imitação, exige do sujeito autor um poder criativo de gerar efeitos de novidade por meio do rearranjo de um código fechado e da imitação e superação de discursos-modelo correlatos a autores consagrados, os quais ameaçam constantemente a autoridade daquele que imita.

Além disso, como prática sócio-discursiva, a literatura seiscentista é regida por uma lógica de mecenato, em que o sujeito-autor é legitimado por sua proximidade em relação às instâncias do poder monárquico. Estar próximo ao rei significava garantir a subsistência e o próprio prestígio. Por isso, o campo literário nos seiscentos não era totalmente autônomo como o descrito por Bourdieu (1996) a partir no século XIX. Os meios de produção, circulação e recepção dos enunciados literários eram restritos às cercanias da corte e ao público seleto da nobreza.

Embora a imprensa já existisse a quase uma centúria, a oralidade e a cultura manuscrita ainda eram marcantes. $\mathrm{O}$ resultado disso é que a presença do nome do autor como responsável pelo discurso ficava em segundo plano. Contudo, Chartier (1999) afirma que no Antigo Regime já havia uma reivindicação pelo nome do autor, tanto para marcá-lo como responsável pelos discursos que produziu quanto como medida de punição por parte da Igreja ou da Coroa.

Em se tratando de regime de autoria, no século XVII, a criação discursiva literária tem a liberdade tolhida pela lógica da imitação e pela rigidez normativa prescrita no código poético-discursivo 
partilhado coletivamente. Fato que faz com que a autoralidade se esvaneça. $\mathrm{O}$ único meio para que a singularidade/identidade do autor aflore no discurso é mostrando seu engenho.

No período barroco, engenho é o nome que se dá a uma habilidade natural que permite ativar certa capacidade excepcional de criação que exige conhecimento da arte, ou seja, dos códigos de composição poético-discursivos, e do decoro dos gêneros, no sentido de respeito ao estatuto enunciativo dos gêneros de discurso. Desse modo, por ser pautada na modalidade verbal da imitação, a produção discursiva literária seiscentista não era vista como original, mas sim como engenhosa, já que dentro de um código de composição "fechado", podia-se produzir enunciados que superassem o modelo.

Todavia, a noção de engenho é válida somente dentro de certos limites, pois a engenhosidade desmedida pode levar a criação de monstruosidades inverossímeis. Conforme a preceptiva retórico-poética seiscentista, no processo de criação, a arte e o decoro determinam limites ao engenho. Mas, na dimensão subjetiva, é preciso juízo para ponderar o furor poético. Almeida (2002, p. 219), em seu tratado de poesia e pintura escrito em 1633, diz ser o "juízo pai do decoro e regra de conveniência”. Desse modo, "o juízo ou a prudência consiste, assim, nas coisas como nas palavras, em que sempre deve haver disposição concertada" ou, ainda, "com a prudência e com o juízo se evitam ações mal ordenadas, torpes prejudiciais, sabendo falar e sabendo calar".

Grande parte dos manuais de escrita do século XVII seguia, como norma preceptiva, a distinção entre juízo e engenho que se fazia na renascença, segundo a qual a primeira noção dizia respeito à condição do aprendizado do código de linguagem literária e do respeito ao estatuto enunciativo dos gêneros de discurso; e a segunda era relacionada à capacidade de criação das agudezas. 
De acordo com Carvalho (2007), desde a antiguidade até o século XVII, a noção de engenho é sempre compreendida com base na ideia de uma habilidade natural ou qualidade inata.

Portanto, se a arte e o respeito ao estatuto enunciativo dos gêneros de discurso são noções basilares no processo de criação partilhado por uma coletividade, o engenho é marca de identidade autoral. Isso quer dizer que nesse regime de autoria o que singulariza o sujeito autor é sua capacidade de mostrar domínio do código de linguagem literária e de rearranjar de maneira criativa discursos-modelo. Soma-se a isso a habilidade de criar agudezas que criem efeitos de sentido inesperados.

\section{A décima de Soror Violante do Céu}

Selecionamos como amostra deste estudo os discursos presentes na décima produzida por Soror Violante do Céu. O enunciado poético em análise segue um estatuto enunciativo epistolar, já que sua situação de enunciação original se enquadra numa cenografia de resposta a uma epístola poética anterior enviada por Gregório de Matos e Guerra. Outra questão a se destacar é o tom epigramático da resposta elaborada pela poetiza barroca ao encerrar em apenas dez versos um pensamento complexo que envolve as relações sócio-discursivas entre homens e mulheres numa sociedade patriarcal como a do século XVII. 


\title{
Contradizer a um Doutor
}

\author{
bem sei que é temeridade; \\ porém com uma verdade \\ quero pagar um louvor. \\ Nem instrumento, nem flor \\ sou, porém, se o posso ser, \\ ninguém trate de emprender \\ o que não há de alcançar: \\ pois nenhum me há de tocar, \\ pois nenhum me há de colher.
}

(CÉU, Violante do. In CARVALHO, 2007, p. 333).

Antes de iniciarmos a análise, é relevante pontuar quem foi a autora Soror Violante do Céu e qual sua importância para a produção de discursos literários seiscentistas. Soror Violante do Céu viveu na primeira metade do século XVII e foi uma freira dominicana que professou no convento de Nossa Senhora do Rosário, da Ordem de S. Domingos. No campo literário, é conhecida pela composição de uma comédia representada durante a visita de Filipe II em Lisboa e também pelas produções poéticas, dando corpo significativo à estética que conhecemos na atualidade como Barroca. Cultivou a vertente conceptista, especificamente de Quevedo, dada sua formação escolástica, explorando enunciados engenhosos que tem como ponto de partida uma construção mental de sutileza intelectual, o que a diferenciava de outras autoras mulheres como Mariana do Alcoforado, cuja vertente se situa mais no sentimentalismo monástico. Moisés descreve Violante do Céu como poetiza entrosada no espírito da Fénix Renascida, exibindo discur- 
sos cujo idealismo projeta mundos impossíveis marcados por antíteses significativas como a morte na vida, a tristeza nas alegrias, que nos levam a refletir a vida corrente do século XVII pelo prisma de um enunciador feminino.

O discurso selecionado como amostra de análise tem sua materialidade constituída por meio de uma décima. Este enunciado poético é entendido neste estudo não apenas como forma de estrofação, mas como um gênero de discurso literário que, no período barroco, tem um estatuto enunciativo muito variado. As décimas eram largamente utilizadas para o exercício poético das glosas, geralmente ocorridas em certames literários nos salões da corte ou nas reuniões das academias de letrados. Nesses locais, declamavam-se poemas, os quais, a depender da fama do autor, eram replicados em manuscritos soltos ou coletâneas. Ademais, no século XVII, havia a prática discursiva das correspondências poéticas, pelas quais se discorria sobre temas muito variados. No caso, dos poetas burlescos e satíricos, enunciados poéticos eram utilizados como forma de galenteio. A décima de Violante do Céu enquadra-se nessa espécie de prática e pretende responder com síntese epigramática aos cortejos sedutores do despudorado poema gregoriano.

Vale salientar que o enunciado poético produzido por Violante do Céu é uma décima espinela. Os poetas barrocos deram preferência a essa variedade que, conforme Chocyai (1993), não apresentava qualquer restrição de conteúdo. Isso permitia que tais composições enunciassem desde temas jocosos ou até mesmo obscenos ao mais edificante pensamento. Nesse sentido, a décima espinela, quando não utilizada como sistema estrófico, tem o mesmo potencial de síntese conceitual que um soneto. Por isso, quando a décima se encera em si mesma como unidade enunciativa muitas vezes, assim como o soneto, é comparada ao epigrama. 
O epigrama em sua origem helênica era um enunciado curto com poder de concisão conceitual e expansão semântica. Tal característica interessa-nos, visto que o discurso de Violante do Céu tem o mesmo potencial. No século XVII, Gracián (1944) via nos enunciados epigramáticos uma forma apropriada para a exibição cortês do engenho. Sendo que a intenção comunicativa desses discursos era refletir sobre a complexidade subjetiva da vida secular, sobretudo, sob o prisma da crítica satírica engenhosa.

O discurso que selecionamos enquadra-se como engenhoso, pois identificamos o estabelecimento de um jogo artificioso de vozes sociais, que nos remetem a formações discursivas disseminadas no mundo tópico das instituições sociais. Também é um discurso que permite a consolidação de um novo lugar enunciativo na proposição de novos conceitos, acerca de um pensamento que se supõe consolidado na época. $\mathrm{O}$ enunciador parte da estratégia de denunciar o co-enunciador de um juízo falho ao conceituá-lo como mulher viciosa, segundo as considerações que o co-enunciador detém sobre o que é ser mulher no século XVII.

O enunciador identifica o co-enunciador como Doutor, alguém que, no século XVII, detém prestígio social frente a outros sujeitos. Por se tratar de um discurso literário que remete às condições sócio-históricas e culturais da metrópole portuguesa, podemos observar que doutor é aquele sujeito que ocupa posição de prestígio na sociedade de Corte, mesmo se tratando de um brasileiro. Nesse período, Gregório de Matos, proeminente advogado e poeta, vivia na capital da metrópole, Lisboa, e era exaltado por sua vocação enunciativa. Conforme Miranda (2014, p. 208) "com a fama de brilhante advogado, celebrado por seu talento poético, Gregório de Matos atiçava a vaidade de homens ilustres e nobres”. Dessa maneira, no olhar do enunciador, o co-enunciador concentra os privilégios de ser homem, em uma sociedade que não ofe- 
rece participação sócio-política à mulher. Os sujeitos do gênero feminino eram considerados discretos quando se enquadravam no conjunto de valores ético-políticos normatizados pelo discurso hegemônico; ou viciosos quando, de alguma, forma subvertiam ou fugiam dos estereótipos de mulher partilhado em tal formação social. Assim, numa perspectiva religiosa, a mulher deveria seguir os princípios de castidade e contenção dos desejos; e de um ponto de vista mundano, deveria submeter-se aos valores patriarcais, ou seja, submissão total aos sujeitos do gênero masculino. Qualquer subversão a essa relação de poder era passível de censura, seja institucional de acordo com o código penal secular ou com a doutrina religiosa, seja via discurso literário, que "punia" tais "delitos" com a malícia erotizante do riso burlesco ou com a maledicência ferina da sátira.

No enunciado Contradizer a um Doutor / bem sei que é temeridade (vv. 1-2), identificamos um primeiro traço de agudeza no discurso selecionado. Compreendemos temeridade como imprudência e é imprudente aquele que, descuidado, age sem sincronia com as normas estabelecidas em uma situação dada. O enunciador que contradiz um doutor é imprudente por não ter a mesma capacidade intelectual que o co-enunciador. Contudo, também pode ser imprudente por, dentro dos limites tópicos instituídos nas práticas sociais, um doutor ter a proteção de sua etnia, de seu gênero sexual e de seu diploma para todas as considerações e leituras de mundo. No discurso, ambas as verdades são possíveis, contudo, o enunciador tende a concordar com o segundo posicionamento, posto que o novo lugar ético que ele inaugura no discurso é aquele que afronta e discorda da racionalidade lógica dos pontos de vista de um co-enunciador doutor.

O uso do operador argumentativo "porém" no enunciado poético seguinte, permite que identifiquemos a influência do discurso 
filosófico como traço de agudeza no discurso em análise. Na perspectiva do enunciador, a lógica acerca de sua condição de mulher tem muitas verdades, todas reconhecidas pelos sentidos de quem as enuncia. O olhar do co-enunciador é um dentre tantos olhares possíveis acerca do tema tratado no discurso, posto que o enunciador observa:

porém com uma verdade quero pagar um louvor. (vv. 3-4)

Ao enunciar uma verdade, o enunciador defende que o ponto de vista de quem enuncia determina a construção sensível da lógica que traduz o sujeito tematizado. $\mathrm{O}$ co-enunciador, dessa maneira, mesmo na posição social de doutor, inquestionável nas instituições e nos lugares tópicos; na situação de enunciação instaurada no enunciado poético passa a assumir uma posição de igualdade em relação ao enunciador. Assim, ocupando ambos uma mesma posição enunciativa, a verdade age conforme as inferências pautadas nas aparências e nas experiências.

O co-enunciador que nos lugares tópicos detém posição de privilégio pela sua condição de doutor, o que implica homem de etnia europeia e diplomado, no enunciado poético assume o papel de mais uma verdade válida dentre tantas outras. Isso se dá, pois o co-enunciador, no olhar do enunciador, tem uma limitação que ofusca sua capacidade de constituir outras verdades. A causa de tal restrição é de natureza sócio-discursiva e demarca uma sensibilidade em catalizar a subjetividade feminina apenas do ponto de vista do discurso autorizado.

O enunciador, por sua vez, pretende pagar um louvor com sua verdade. Nesse caso, há uma referência à situação de enunciação em que a décima como gênero de discurso está inserida. Tal refle- 
xibilidade enunciativa, diz respeito à prática sócio-discursiva de enviar epístolas poéticas a mulheres com intuito de galanteá-las. Muitas vezes a forma de cortejo era por meio do elogio à beleza da mulher. Por isso, a expressão pagar um louvor. Ocorre que no âmbito religioso esses louvores profanos se realizam na lógica do amor freirático. Nesse caso, religiosas que sucumbiam aos desejos carnais eram consideradas sujeitos viciosos que deveriam sofrer as censuras da maledicência e não os elogios do louvor, conforme rege o estatuto pragmático do gênero retórico demonstrativo que previa normas enunciativas para o louvor e o vitupério. Por isso, é preciso desfazer os mal-entendidos com uma verdade a ser revelada: o enunciador não se enquadra na imagem estereotípica da mulher viciosa, mas sim no da mulher discreta que segue o código ético-político partilhado pela Sociedade de Corte portuguesa e vai além dele.

Contudo, para tanto é preciso subverter as relações de poder e falar no mesmo nível que um sujeito de gênero masculino, instituindo para si a mesma autoridade enunciativa. Dessa maneira, o enunciador explora as condições de um lugar paratópico no século XVII: é impossível descredenciar um doutor senão no discurso, criando as condições para tal. Apesar disso, é somente no discurso e pelo discurso que se abre a possibilidade de credenciar a intelectualidade de um doutor. Nesse espaço proposto pelo enunciador, o co-enunciador é um doutor incapaz de enxergar o espectro complexo da mulher em sua sociedade, o que depõe contra a intelectualidade originária que dá forças e base para sua função social, mas que confirma um comportamento recorrente na época.

Identificamos que o enunciador, então, consolida um espaço que descredencia a razão de um discurso anterior proferido pelo co-enunciador, nos enunciados: 


\author{
Nem instrumento, nem flor \\ sou, porém, se o posso ser, \\ ninguém trate de empreender \\ o que não há de alcançar ( vv 5-8):
}

Nos enunciados nem instrumento, nem flor / sou, o enunciador responde àquilo que o co-enunciador possivelmente enunciou em outro discurso. Além disso, pode estar respondendo ao que representa o posicionamento do autor da epístola poética acerca do enunciador: é instrumento; é flor. Na condição de instrumento, o enunciador nega ser objeto constituído por várias peças, que serve para executar um trabalho ou uma ação física qualquer. Não podemos deixar de identificar a possibilidade de a voz enunciativa sugerir uma sexualidade sobre a condição de instrumento ofertada à mulher por homens doutores no século XVII. Ainda, por mulheres freiras que, costumeiramente, mantinham relações sexuais com estudantes universitários em Portugal.

A categoria de instrumento para a mulher é um estigma comum à época. $\mathrm{O}$ mesmo se dá à condição de flor, e o enunciador observa que não é uma simples estrutura reprodutiva, um ornamento a ser apreciado, livre de impurezas, amável e de bons sentimentos, a serviço do co-enunciador. A condição de ser flor, semanticamente está mais próxima da erotização que ser instrumento, posto que a flor se trata, no século XVII, de um marcador de discurso literário que atua como metáfora reconhecida para a designação sensual e burlesca do órgão genital feminino. Ser flor implica ser sexualmente amável ao homem, enquanto objeto de prazeres e contentamentos.

Em seguida, o enunciador novamente utiliza operador argumentativo porém, com o intuito de introduzir uma situação adversativa dentro da possibilidade de verdade criada pelo co-enunciador: 


\section{(...) porém, se o posso ser, \\ ninguém trate de empreender \\ o que não há de alcançar (vv. 6-8):}

O uso da palavra "porém" introduz uma nova verdade desconhecida pelo co-enunciador. $\mathrm{O}$ enunciador observa que, mesmo diante da possibilidade de ser instrumento e flor, diferente do que é posto no imaginário institucional, ele tem escolhas sobre si mesmo e empreende sua sexualidade como bem entende. Identificamos estes enunciados como engenhosos, pois permitem uma dubiedade de efeitos de sentido, a partir do regime de autoria do enunciador. Se, na interação enunciativa, o discurso for tomado pelo filtro semântico de um enunciador porta-voz das mulheres, o enunciador reivindica o controle do corpo da mulher pela própria mulher, sendo este flor e instrumento que homem algum há de alcançar. Novamente, compreendemos que essa verdade sobre a mulher e sua relação com seu corpo nas práticas sociais do século XVII pode ser uma consciência simbólica de si, mas com pouca força. Isso porque a reificação do corpo feminino e construção de sua sexualidade são naturalizadas a partir de um posicionamento discursivo patriarcal detentor das verdades, sendo a consciência de si e o domínio do corpo, uma exceção.

Por sua vez, o discurso permite que o co-enunciador tome o enunciador pelo filtro semântico da mulher freira e intelectualizada o que a enquadra no espectro estereotípico da mulher discreta. Dessa maneira, o enunciador é porta-voz de uma parte seleta de mulheres que tem consciência de si e não se enquadram no mesmo perfil de mulheres reificadas e hipersexualizadas. Ao contrário dessas últimas, as mulheres discretas, no século XVII, têm a face preservada sob o manto da pureza, do controle das emoções e da moralidade. 
Dentro das devidas proporções, a mulher discreta tem a possiblidade de tomar a palavra. Assim, o uso do verbo "tratar" no enunciado "ninguém trate de empreender" (v. 7) possibilita uma reflexão sobre como a engenhosidade do discurso possibilita um poder de legitimidade enunciativa. $\mathrm{O}$ uso do item lexical trate nos permite identificar uma voz imperativa, que incide em uma ordem ao co-enunciador de como ele não deve proceder perante uma mulher freira e intelectualizada, ou frente às mulheres em geral. Nesse caso, trata-se de uma voz subjetiva, possibilidade dentre tantas outras, considerando esta uma verdade a mais de como proceder na relação com uma mulher. A dubiedade imperativo/subjuntivo implica uma engenhosidade do discurso que provoca o co-enunciador a se sentir desconfortável em seu espaço de poder. É possível que o co-enunciador questione se estaria recebendo uma ordem direta de alguém que se iguala a ele nesse novo lugar de enunciação, ou estaria recebendo uma orientação, que pode acatar ou não na vida social. Todavia, o mais prudente nesse espaço paratópico do discurso, é seguir as recomendações do enunciador, que oferece poucas opções morais para desvirtuar como proceder.

Nesse sentido, compreendemos, por fim, que o discurso literário analisado produz, tal qual os epigramas, uma reflexão complexa por meio da qual se busca edificar um novo lugar moral, para além do código ético-político legitimado. O poder reflexivo busca, em um enunciado curto que se expande semanticamente através de efeitos de sentido engenhosos, as agudezas, traçar novas formas de definir o que é certo e o que é errado no tratamento da mulher no século XVII. Tudo isso, por meio de um posicionamento enunciativo feminino.

O discurso engenhoso instaura a possibilidade de novas enunciações ou de mundos possíveis, segundo o princípio da verossimilhança, em que a poética da imitação determina que se imite não 
o igual, mas o semelhante; não o particular, mas o universal das coisas. Nesse caso, há uma relação interdiscursiva entre o discurso filosófico e o literário. No século XVII, busca-se principalmente encontrar o universal no aparente das coisas e é por meio do olhar aguçado do filósofo ou do letrado que isso é possível.

O enunciador do discurso de Violante do Céu procura mostrar o equívoco existente entre a aparência e a essência no enunciado poético dedicado a uma respeitada religiosa na forma de galanteio elogioso e, com isso, revelar uma verdade: a mulher em essência é um ser virtuoso, dona de seu próprio corpo e com poder intelectivo igual ou superior a um sujeito do gênero masculino. Mas isso só é possível, por meio do manejo excepcional do código de linguagem literária que prevê normas rígidas de composição e o conhecimento do estatuto enunciativo dos gêneros de discurso. Por isso, é o engenho do autor que o legitima e que, ao mesmo tempo, precisa ser legitimado na própria cenografia instaurada no enunciado poético. É somente na fronteira entre a essência e a aparência, entre o mundo e os mundos possíveis da poética da imitação que se pode re-criar um universo de valores ético-políticos capazes de desmantelar as imagens estereotípicas de mulher partilhadas em uma sociedade patriarcal.

Por isso, consideramos paratópica as possibilidades de existência de tal discurso, posto que o enunciador é porta-voz de um tipo de mulher que existe e não existe naquela sociedade, em lugares sociais que se desenham masculinizados. O olhar da sociedade tem o filtro do gênero sexual masculino e o enunciador propõe uma verdade outra sobre os sentidos que as instituições sociais ofertam às coisas do mundo. Sob as nuances semânticas que desvelam os traços indenitários de um enunciador mulher, há mais verdades a se considerar sobre o mundo, talvez desconhecidas pelo co-enunciador doutor. 


\section{Considerações Finais}

Compreendemos, ao término dessa pesquisa, que o discurso literário seiscentista implica um regime de autoria, cujos fundamentos estão na imitação de discursos-modelo. A repetição das tópicas do código de escrita retórico-poético se justifica para potencializar os desdobramentos do enunciador sobre o mundo ético-moral o qual ele se insere. As rotinas enunciativo-discursivas de gêneros de discurso literário como a décima amplificam a capacidade do enunciador em criar um lugar de ética e moralidade que pode servir para o co-enunciador ressignificar suas matrizes culturais e sociais. A abordagem do erotismo mundano, dessa maneira, não implica ao discurso um traço de atopia, ou uma restrição social. Dada a capacidade de engenho do enunciador em se projetar como autor de um discurso literário, o erótico é ponto de partida para explorar verdades visíveis no mundo social, mas pouco conhecidas pelo co-enunciador.

Identificamos, por fim, que o discurso literário analisado se apropria do erótico como forma de introduzir ao co-enunciador novos lugares e novos papeis que transcendam os lugares e os papeis legitimados pelas instituições sociais do século XVII. Dessa maneira, o discurso literário se faz constituinte pela engenhosidade do enunciador que, pela décima, reflete certas práticas reprimidas pelo código ético-político seiscentista, encontrando um lugar provisório de existência, que tenha verossimilhança com as verdades do co-enunciador e também lhe gera sentimentos de deleite e aprendizado. 


\section{Referências}

ALMEIDA, Manual Pires. "Poesia e Pintura ou Pintura e Poesia". In MUHANA, Adma. Poesia e pintura ou pintura e poesia: tratado seiscentista de Manuel Pires de Almeida. Traduções latinas de João Ângelo Oliveira Neto. São Paulo: Edusp / FAPESP, 2002.

ARISTÓTELES. Retórica. São Paulo: Rideel, 2007. . Arte retórica e arte poética. Tradução Antônio Pinto de Carvalho. Rio de Janeiro: Ediouro, s/d.

BAUMAN, Z. Modernidade e Ambivalência. Tradução Marcos Penchel. Rio de Janeiro: Jorge Zahar Ed., 1999.

BOURDIEU, Pierre. As regras da arte: gênese e estrutura do campo literário. Tradução Maria Lúcia Machado. São Paulo: Companhia das Letras, 1996.

CARVALHO, M.S.F. Poesia de agudeza em Portugal. São Paulo: Humanitas; Edusp; FAPESP, 2007.

CHARTIER, R. "Por uma Sociologia histórica das Práticas culturais", In:_. História Cultural: entre Práticas e Representações. Rio de Janeiro: Bertrand Brasil, 1990.

GASSENDI, Pierre. Opera Omnia. Ed. Tullio Gregory. SttugartBad Cannstatt: Friedrich Frommann Verlag, 1964.

GRACIÁN, B. Artifício y Arte de Ingenio. Obras Completas. Madrid: Aguilar, 1960.

LEIBNIZ. Princípios de filosofia ou Monadologia. Tradução, introdução e notas de Luís Martins. Imprensa Nacional - Casa da Moeda, 1987.

LEIBNIZ. Novos ensaios sobre o entendimento humano. Coleção Os Pensadores, São Paulo: Nova Cultural, 1992. Volumes I e II MAINGUENEAU, D. Cenas da Enunciação. São Paulo: Parábola, 2008. 
. Discurso e Análise do Discurso. Tradução: Sírio Possenti. 1.ed. São Paulo: Parábola, 2015.

MIRANDA, Ana. Boca do inferno. São Paulo: Companhia das Letras, 1993.

. Musa Praguejadora: a vida de Gregório de Matos. Rio de Janeiro: Record, 2014.

MUHANA, Adma. A epopéia em prosa seiscentista: uma definição de gênero. São Paulo: UNESP, 1997.

. Poesia e pintura ou pintura e poesia: tratado seiscentista de Manuel Pires de Almeida. Traduções latinas de João Ângelo Oliveira Neto. São Paulo: Edusp / FAPESP, 2002.

TEIXEIRA, Ivan. (Org.). Música no parnaso: Manuel Botelho de Oliveira. A poesia aguda do engenhoso fidalgo Manuel Botelho de Oliveira. Edição fac-similar. São Paulo: Ateliê, 2005. 